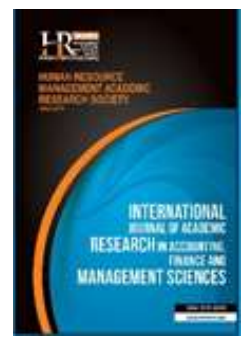

International Journal of Academic Research in Accounting, Finance and Management Sciences

Vol. 9, No.4, October 2019, pp. 1-9

E-ISSN: 2225-8329, P-ISSN: 2308-0337

(c) 2019 HRMARS

www.hrmars.com

To cite this article: Rumambi, H., Kaparang, R., Lintong, J., Tangon, J. (2019). The Building Blocks to Construct

Financial Statement of Micro, Small, and Medium Enterprises (MSMEs) of Rice Farmers Groups, International

Journal of Academic Research in Accounting, Finance and Management Sciences 9 (4): 1-9

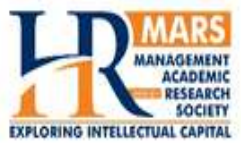

http://dx.doi.org/10.6007/IJARAFMS/v9-i4/6627 (DOI: 10.6007/IJARAFMS/v9-i4/6627)

\title{
The Building Blocks to Construct Financial Statement of Micro, Small, and Medium Enterprises (MSMEs) of Rice Farmers Groups
}

\author{
Hedy Rumambi ${ }^{1}$, Revleen Kaparang ${ }^{2}$, Jerry Lintong ${ }^{3}$, Joseph Tangon ${ }^{4}$ \\ 1,2,3,4 Manado State Polytechnic, Polytechnic Highway Buha Village, Manado, Indonesia; \\ ${ }^{1}$ E-mail: hedydr@yahoo.com (Corresponding author), ${ }^{2} E$-mail: revleen12@gmail.com, \\ ${ }^{3}$ E-mail: jerrylintong@gmail.com, ${ }^{4}$ E-mail: joseph.tangon@gmail.com
}

\begin{abstract}
What are the elements of financial statement making for MSMEs of rice farmers groups? Statement of Financial Accounting Concepts (SFAC) number 6 states that the elements of the financial statement are building blocks that construct the financial statement. Much MSMEs management in Indonesia does not understand the concept of financial reports so they have difficulty in preparing them. Therefore, this research aims to describe the elements that form the financial statement of MSMEs of rice farmers groups in Indonesia. This research uses a qualitative research method. We collect the data through in-depth interviews with the chairs of rice farmers groups about the scope of a business, business activities, and transactions that occurred. After that, we conducted an analysis and interpretation data through the process of identification and classification of data and presented them in the form of classification of MSMEs' transactions. This classification describes the elements that make up the MSME financial statements. This research results in a description of assets, liabilities, equity, income, and expense of MSMEs of rice farmers groups. The description of these elements is a representation of the economic phenomena of MSMEs that obtained from the scope of business and transactions, which occur of the activities of rice planting, rice harvesting, and rice post-harvest. The results of this study will help the management of MSMEs in making their financial statements.
\end{abstract}

Key words MSMEs of rice farmers groups, business scope, business activities, financial transaction, the elements of financial statement

Received: 15 Nov 2019 (C) The Authors 2019

Revised: $\quad 30$ Nov 2019 Published by Human Resource Management Academic Research Society (www.hrmars.com)

Accepted: 03 Dec 2019 This article is published under the Creative Commons Attribution (CC BY 4.0) license. Anyone may reproduce, distribute, translate and create derivative works of this article (for both commercial and non-commercial purposes), subject to full attribution to the original publication and authors. The full terms of this license may be seen at: http://creativecommons.org/licences/by/4.0/legalcode

\section{Introduction}

A financial statement is an essential element to the survival of an entity. All financial activities of a company are recorded in the financial statement. Financial statement becomes a tool to present financial information (Didin et al., 2018). The completed, objective, and reliable financial statement is used to form an opinion regarding property and the company's financial position (Thalassinos and Liapis, 2014). Various parties, both internal and external of the company for decision-making, use the financial information.

Besides presenting the financial information, financial statement is also as a means to the user for measuring the performance of the company. The assessment of the company's performance is done by the evaluation of the past and present financial position (Osadchy et al., 2018). One of the parties that are interested in the financial statement is financial institutions or banks. They need a financial statement from the business entity to assess the feasibility of their business as a basis to provide a loan. 
The government of Indonesia, in relation to assist MSMEs is endeavored to provide financial assistance through the bank. Bank of Indonesia has issued a regulation that requires banks to allocate funding to MSMEs at the end of 2018 by $20 \%$ (Bank of Indonesia and the Institution of Indonesian Banking Development, 2015). To obtain a loan from the bank, MSMEs need to prepare financial statements (Warsono et al., 2010). Several previous studies found that accounting recording made by MSMEs still very simple (Risnaningsih et al., 2018). Many MSMEs do not make any recording of their financial transactions (Risnaningsih and Tanuwidjaja, 2015; Risnaningsih and Suhendri, 2015).

The Financial Accounting Standards of Micro, Small, and Medium Entities (FAS of MSMEs) are prepared to assist the MSMEs management in constructing financial statements for making them easier to get access to funding from the financial institution. On the other hand, the scope of MSMEs business has different characteristics so that the elements of financial statements specifically follow the characteristics of each type of MSME.

In general, the elements of a financial statement consists of assets, liabilities, equity, income, and expenses (Institute of Indonesia Chartered Accountants, 2018a). Recognition of the elements of financial statement is the process of forming an account (description of the element) in the statement of financial position or income statement. The description must meet the definition of the elements of the financial statements (Institute of Indonesia Chartered Accountants, 2018a). To present these elements in the financial statements requires a sub-classification process (Institute of Indonesia Chartered Accountants, 2018b). The formation of the elements becomes the starting point in the preparation of the financial statement. Therefore, this study aims to describe the elements that make up the financial statement of MSMEs of rice farmers groups.

\section{Literature review}

An entity must consider the concept of a business entity as its essential thinking to make financial statements. For individual businesses, an entity needs to make the company clearly between the business owner and its business entity. Owner transactions must be separated from the entity business transaction (Institute of Indonesia Chartered Accountants, 2018). In this perspective, the company is seen as a separated and different entity from its owner (Kieso et al., 2011). From this business entity concept flows the need for the financial report.

Financial statement is the primary way to deliver financial information to an external party of company and to describe the company's condition measured by money (Kieso et al., 2011). The financial statement uses a tool, analytical technic, and method that are needed for business analysis (Hasanaj and Kuqi, 2019). The purpose of a financial report is to provide financial information of an entity that is useful for various users in making an economic decision (Okoye and Akenbor, 2014).

The compiling of the financial statement is carried out to fulfill the transparency and accountability aspects of the financial report of an entity. Transparency in a financial report is needed through financial information disclosure. It is free of bias for an internal and external user in making analyses and decisions for the purpose of short-term and long-term investment (Rashid et al., 2018). Transparency means the information contained in the report can be accessed and understood by all market participants. There are three main groups of market participants, namely borrowers and lenders, issuers and investors, as well as national authorities and international financial institutions. Transparency is needed in implementing the accountability of financial statements among the three groups (Lepădatu and Pîrnău, 2009).

The financial statement of an entity is not only made for internal users but also external stakeholders. It is essential to understand the needs of these stakeholders so that financial statements can be made according to those needs. To that point, the organization has to be managed for the interest of all stakeholders, and not only for the benefit of financial shareholders (Smith, 2015). Users of financial statements consist of potential investors, employees, lenders, suppliers, and other trade creditors, customers, government, and the public (Ankarath et al., 2015).

As a business language, accounting is used to provide financial information in a financial report. Information will be useful if it is presented in a way that is relevant, reliable, and consistent (Azim and Ara, 2015). Therefore, the financial statement becomes a media of accountability for stakeholders. 
The financial statement also shows the results in managing the resources that are entrusted to manage. In accordance with FAS of MSMEs, the minimum financial statement consists of the statement of financial position at the end of the period, the income statement for the period, and the notes of financial statement (Institute of Indonesia Chartered Accountants, 2018a). The statement of financial position includes information about the assets, liabilities, and equity of the entity at a specific date. The income statement contains information about the financial performance of the entity, which consists of income and expenses during the reporting period. The notes of financial statements contain additional and detail of certain relevant items.

SFAC number 6 explains that the elements of financial statements are the building blocks to construct a financial statement (FASB, 2008). The items in financial statements represent specific entity resources, claims to those resources, and the effects of transaction and other events as well as other conditions that change these resources and claims. Therefore, the elements in the financial statement must be able to represent the accounting information precisely from the phenomena that are to be represented.

The information must be relevant and faithfully represented to fulfill the fundamental qualitative characteristics of financial information. Financial information is useful if the information is relevant and represents what will be described (Institute of Indonesia Chartered Accountants, 2018b).

Faithful representation if the elements of financial statements are formed based on economic phenomena arising from transactions, events, and circumstances that exist in the entity. Relevant means the financial information submitted is useful for users of financial statements. To be relevant and faithfully represented, the financial information described in the financial statements must reflect the business characteristics of the entity. According to the FAS of MSMEs (Institute of Indonesia Chartered Accountants, 2018a), the elements of the financial statement are as follows:

a. Asset is a resource that is controlled by an entity as a cause of past events and from which future economic benefits are expected to flow to the entity.

b. Liability is the current entity obligation emerging from a past event where its reimbursement is estimated to result in the outflow of entity resources that contain economic benefits.

c. Equity is the residual rights to the entity asset after all liabilities have been deducted.

d. Income is an increase in future economic benefits relating to an increase in an asset or a decrease in liability.

e. Expense is a decrease in future economic benefits relating to a decrease in an asset or an increase in liability.

To compile the financial statement, MSMEs need to understand that there are five elements of a financial statement. These elements as stated in MSMEs' financial accounting standards are still general. Different business characteristics of MSMEs cause different items descriptions of financial statements elements. The concept of the existing financial statement elements becomes a guide for the selection of transactions, events, and circumstances that must be accounted for. Entities need to describe these five components in more specific items through a sub-classification process (Institute of Indonesia Chartered Accountants, 2018b).

The sub-classification process is the process of classifying the elements of financial statements more precisely by the business characteristics of the entity and the real economic phenomena. The nature and function of these elements to produce information that is useful in making financial decisions. The characteristics of the entity's business and economic phenomena in question include the scope of a business, business activities, transactions that occur. These three indicators become the sources of information to describe the specific entity resources, claims against those resources, and the impact of transactions and other events. Therefore, Figure 1 shows the research framework for describing the building blocks of MSMEs' financial statements for rice farmers. 


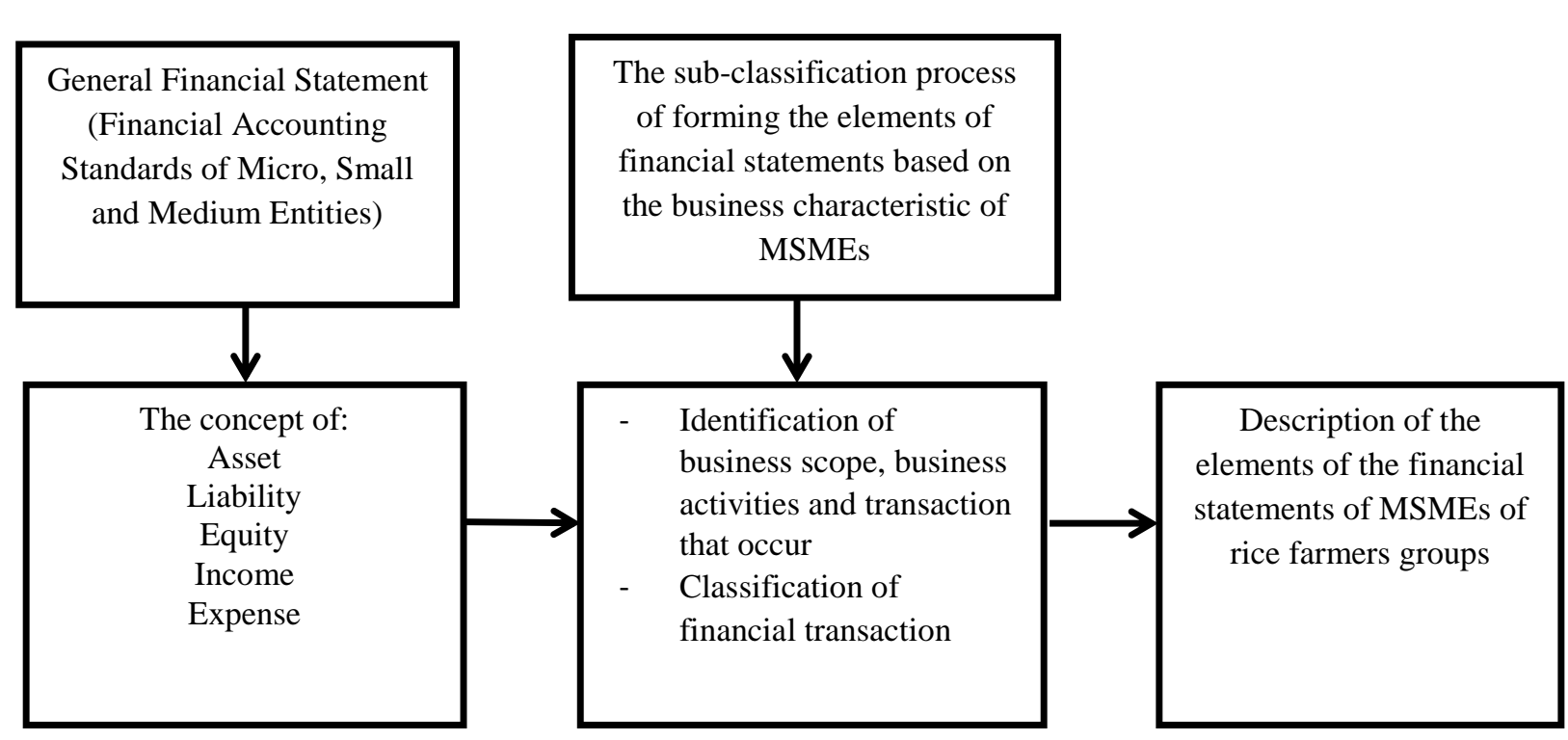

Source: compiled by the authors, 2019

Figure 1. Research Framework

\section{Methodology of research}

This research uses a qualitative research method. There are three stages in carrying out the qualitative data description. First, we conduct data collection through in-depth interviews with leaders of rice farmers groups. We use 50 informants who are in the area of North Sulawesi. The determination of the informants with the consideration that North Sulawesi is one of the rice-producing regions in Indonesia and has many groups of rice farmers. Data collection refers to the scope of MSMEs' business, their activities, and transactions that occur. Second, we analyze and interpret the data through the process of subclassification, include identification and classification process, and present the various existing data according to the themes found - the presentation of data in the form of a classification of MSMEs transactions. Third, we describe the elements of MSMEs' financial statements.

\section{Results and discussions}

Based on the results of an in-depth interview with the informants, we found the following things.

a. The Scope of Business

Rice farmers groups produce rice. From the results of rice, production also obtained grain. The farmer group has 20-25 members. The level of education of farmers is at the junior and senior high schools. The organizational structure consists of the chairman, secretary, treasurer, and members. Their source of capital comes from government assistance and group members. The rice production cycle is three months. They used jajar legowo (Indonesian terms) as a planting system. The land for rice planting is the agricultural land of the members. They do simple bookkeeping in the form of a daily cashbook their purchase and selling transaction in cash and credit. The sources of fixed assets are from members, rent, purchasing, and government assistance. The types of fixed assets such as agricultural land, tractors/plow machine, and equipment such as thresher tool, hand spray, and sickle. The supplies include sacks, tarpaulins, nets, and pans.

b. Business activities and identification of transaction that occur

There are three main activities, those are:

1) Rice planting

Rice planting activities consist of:

a) Land preparation

The rice farmers groups use the member's land to grow rice. The process of preparing the area is 3-4 days by plowing. The farmers cultivate by using rice fields plow machine. The machine is their own or rented. Besides that, farmers also provide fertilizer for the land. They hire the workers to work land 
preparation. Commercial activities that occur in this process include renting of plow machine or purchasing of plow machine, payment of workers' wages, fertilizer purchase, fuel purchase (gasoline/diesel).

b) Nursery

The farmers have seeds through exchange with other groups, donations, or purchased. Farmer groups prepare workers who will make beds and seeding. Financial activities that occur include seeds purchase or getting seed from support, as well as payment of workers' wages.

c) Planting

The farmers transfer the seeds that are ready to plant to a plot (planting area). They use jajar legowo planting system by 2:1. The farmers set the planting space by following the direction of the existing rope. Farmer groups hire people who will carry out the planting process. The financial transaction that occurs related to rope purchase activities and payment of workers' wages.

d) Maintenance

There are two-stages of maintenance:

- The farmers do stage one when the rice is 3 to 4 weeks old. They do the replanting process to control the growth of seedlings, rice age, and water mass. Besides, weeding, fertilizing and spraying of pests for the prevention of pests and diseases.

- The farmers do stage two when the rice is 7-8 weeks old. They carry out the weeding, fertilizing, and pest management. Besides, they make various efforts to protect biological assets or plants from bird disturbance by preparing safety nets. Identification of transaction that occurs consists of payment of workers' wages for each activity, purchase of pesticides, purchase of spray pests, purchase of fertilizer, and purchase of nets.

2) Rice harvest

There are two activities related to the rice harvest process, namely:

a) Rice harvest

At this stage, the farmers cut and collect the rice at a shelter. They carry out harvesting manually and collect the harvested rice to a place close to threshing tools. To reduce yield losses, they line the collection point with tarps. Identification of transaction that occurs consists of payment of workers' wages, purchase of tarps, and purchase of harvesting equipment.

b) Rice threshing

After the rice cut, the farmers carry out the harvest. Rice harvesting is one of the post-harvest stages that contribute significantly to the loss of yield and quality of rice overall. For this reason, they make an effort to find an appropriate threshing alternative so that the return of threshing rice produces quality grain and loses yields are small. Financial activities that occur are the payment of workers' wages and the rental of vehicles to transport the harvested rice. They also purchase of supporting materials separately to help the rice harvest process, such as the purchase of tarp, pans, and sacks.

3) Rice Post-harvest

Activities carried out by farmer groups in post-harvest of rice are:

a) Drying

The farmers carry out the drying process generally by utilizing the heat of the sun (drying). After they dry the grain in the sun, the next step, they clean the dried grain, store, or grind it directly to produce rice ready to sell. Financial activity that occurs in this activity is the payment of workers' wages.

b) Milling

After drying, the farmers ground the rice in a mill. Grinding is a process of removing grain coating, both traditional and modern. Financial activities in this activity are the expense of renting equipment to grind the rice harvest and pay for transportation to transport the rice harvest to the mill. After finishing the milling, the farmer groups get agricultural products (rice) that are ready to sell.

c) Selling of rice and grain

The farmers sell rice in markets or stores. They sell the grain at the mill. Related activities include the transaction of selling rice and grain.

c. Classification of transaction 
International Journal of Academic Research in Accounting, Finance and Management Sciences

Vol. 9 (4), pp. 1-9 $\odot 2019$ HRMARS (www.hrmars.com)

Table 1. Classification of MSMEs Transaction of Rice Farmers Group

\begin{tabular}{|c|c|c|}
\hline Business Activities & Transaction that occurs & $\begin{array}{l}\text { The Classification of financial } \\
\text { transactions }\end{array}$ \\
\hline \multicolumn{3}{|l|}{ Rice Planting } \\
\hline 1. Land preparation & $\begin{array}{l}\text { Rent of plow machine } \\
\text { Purchase of plow machine } \\
\text { Payment of worker's wages } \\
\text { Purchase of fertilizer } \\
\text { Purchase of fuel (gasoline or solar) Provision of } \\
\text { agricultural land }\end{array}$ & $\begin{array}{l}\text { Machine rent expense } \\
\text { Machine } \\
\text { Wages expense } \\
\text { Fertilizer expense } \\
\text { Fuel expense } \\
\text { Agricultural land }\end{array}$ \\
\hline 2. Nursery & $\begin{array}{l}\text { Purchase of seeds } \\
\text { Get of seeds donation } \\
\text { Payment of worker's wages }\end{array}$ & $\begin{array}{l}\text { Seeds purchase expense } \\
\text { Donated capital } \\
\text { Wages expense }\end{array}$ \\
\hline 3. Planting & $\begin{array}{l}\text { Purchase rope } \\
\text { Payment of wages }\end{array}$ & $\begin{array}{l}\text { Supplies expense } \\
\text { Wages expense }\end{array}$ \\
\hline 4. Maintenance & $\begin{array}{l}\text { Payment of worker's wages } \\
\text { Purchase of pest drugs } \\
\text { Purchase of pest spray tool } \\
\text { Purchase of fertilizer } \\
\text { Purchase of nets }\end{array}$ & $\begin{array}{l}\text { Wages expense } \\
\text { Pest drugs expense } \\
\text { Equipment } \\
\text { Fertilizer expense } \\
\text { Supplies expense }\end{array}$ \\
\hline \multicolumn{3}{|l|}{ Rice Harvest } \\
\hline 1. Rice harvest & $\begin{array}{l}\text { Payment of worker's wages } \\
\text { Purchase of tarp } \\
\text { Purchase of harvest tool }\end{array}$ & $\begin{array}{l}\text { Wages expense } \\
\text { Supplies expense } \\
\text { Equipment }\end{array}$ \\
\hline 2. Rice Threshing & $\begin{array}{l}\text { Payment of worker's wages } \\
\text { Payment of vehicle rent } \\
\text { Purchase of tarp, pans, and sacks }\end{array}$ & $\begin{array}{l}\text { Wages expense } \\
\text { Vehicle rent expense } \\
\text { Supplies expense }\end{array}$ \\
\hline \multicolumn{3}{|l|}{ Rice Post-Harvest } \\
\hline 1. Drying & Payment of worker's wages & Wages expense \\
\hline 2. Milling & $\begin{array}{l}\text { Expense of equipment rent for milling the yields } \\
\text { Payment of transportation to transport the yields to } \\
\text { the milling place }\end{array}$ & $\begin{array}{l}\text { Milling expense } \\
\text { Transportation expense }\end{array}$ \\
\hline 3. Selling & $\begin{array}{l}\text { Rice selling } \\
\text { Grain selling }\end{array}$ & $\begin{array}{l}\text { Rice selling } \\
\text { Grain selling }\end{array}$ \\
\hline \multicolumn{3}{|l|}{ Other activities } \\
\hline Sources of capital & $\begin{array}{l}\text { Government Aid } \\
\text { Member of the group }\end{array}$ & $\begin{array}{l}\text { Donated capital } \\
\text { Owners' capital }\end{array}$ \\
\hline $\begin{array}{l}\text { Cash and credit } \\
\text { transaction }\end{array}$ & $\begin{array}{l}\text { Cash transaction } \\
\text { Credit transaction (purchasing) } \\
\text { Credit transaction ( selling) }\end{array}$ & $\begin{array}{l}\text { Cash } \\
\text { Account payable } \\
\text { Account receivable }\end{array}$ \\
\hline
\end{tabular}

Source: compiled by the authors, 2019

According to SFAC no. 6, the items in the financial statements describe the entities' resources. The items also show claims for existing resources, the impact of transactions, and other events, as well as other conditions that change these resources and claims. The scope of business and MSMEs transactions arising from their business activities provide information about their resources, claims, and the impact of MSME transactions. Various financial transactions, as listed in Table 1, show the results of the classification of existing data.

MSMEs' management needs to analyze each event, transaction, circumstance, or information relevant to their business activities. Such analysis to identify the effect of all these conditions on the formation of the financial statement component. Selling transactions form income. Information about the resource of capital forms the element of equity. The source and type of fixed assets form the asset. Assets and liabilities represent cash and credit transactions. Likewise, assets, equity, income, and expense are a representation of business activities and transactions that occur. 
As a business entity, MSMEs management needs to prepare financial statements that provide information about the achievement of performance and financial position at a specific time. Income and expense transactions describe changing in resources and claims such, an increase or a decrease in future economic benefits relating to an increase or a reduction in an asset or else a decrease or an increase in liability. Income and expense information provides an overview of MSME financial performance source of income from rice and grain selling. The expenses emerged, including expenditures for machine rental, payment of wages, fuel purchase, seed purchase, fertilizer purchase, supplies, transportation, vehicle rental, milling, and pest drug (Table 1). Besides, cash accounts, account receivable, machinery, equipment, agricultural land, account payable, and capital describe MSMEs' resources and claims. This information presented the financial position of MSMEs. The following table shows the results of the description of the MSMEs' financial statement elements of rice farmers.

Table 2. Description of the Elements of MSMEs Financial Statement of Rice Farmers Group

\begin{tabular}{|l|l|l|}
\hline \multicolumn{1}{|c|}{ Financial Statement } & \multicolumn{1}{|c|}{$\begin{array}{c}\text { The Elements of Financial Statement } \\
\text { (FAS of MSMEs) }\end{array}$} & $\begin{array}{l}\text { Description of the Elements of Financial } \\
\text { Statement of MSMEs }\end{array}$ \\
\hline Statement of Financial Position & Asset & $\begin{array}{l}\text { Cash } \\
\text { Account Receivable } \\
\text { Agricultural Land } \\
\text { Machine } \\
\text { Equipment }\end{array}$ \\
\cline { 3 - 3 } & & Account Payable \\
\cline { 2 - 3 } & Liability & $\begin{array}{l}\text { Owners' Capital } \\
\text { Donated Capital }\end{array}$ \\
\cline { 2 - 3 } & Equity & $\begin{array}{l}\text { Rice Selling } \\
\text { Grain Selling }\end{array}$ \\
\hline Income Statement & Income & $\begin{array}{l}\text { Machine rent expense } \\
\text { Wages expense }\end{array}$ \\
& & Fertilizer expense \\
& Expense & Fuel expense \\
& & Seeds purchase expense \\
& & Supplies expense \\
& & Pests drugs expense \\
Vehicle rent expense & Milling expense \\
& & Transportation expense \\
\hline & &
\end{tabular}

Source: compiled by the authors, 2019

Table 2 illustrates the building blocks that build the financial statements of MSMEs of rice farmers. MSMEs management requires the concept of the elements that form the financial statements to assist them in preparing financial statements. It is significant because the leaders and members of rice farmers' groups have limited knowledge; their level of education at the junior and senior high school levels. Their limited knowledge resulted in MSMEs accounting records only in the form of a daily cashbook. The existence of the daily cashbook has not been able to provide adequate and transparent information to users of financial statements.

The delivery of information in the financial statements reflects the transparency aspects of MSMEs activities. By preparing a business report, MSMEs management can provide accountability for its operations to stakeholders, namely the government, group members, and the community. The information contained in the MSMEs' financial statements becomes relevant and represents the existing phenomena. The scope of the business, business activities, and transactions that occur become the indicator to prepare the elements of the financial statements. It is possible because the three indicators represent the characteristics of MSMEs businesses. 


\section{Conclusions and recommendations}

In general, assets, liabilities, equity, income, and expenses are the building blocks for constructing MSMEs' financial statements (Institute of Indonesia Chartered Accountants, 2018a). This concept needs to be adapted to the type of MSMEs business because the characteristics and business fields of MSMEs vary. The differences in MSMEs' characteristics and business sectors produce gaps in the elements that make up MSMEs' financial statements.

The scope of business and transactions that occur from MSME business activities provide information that reflects the relevant financial transactions of MSMEs of rice farmers groups. The implementation of the sub-classification process, through identification and classification, results in the classification of financial transactions that represent the MSMEs' economic phenomena faithfully. The results of the classification describe the elements that form the financial statements of MSMEs of rice farmers groups. The description of these elements (as listed in Table 2) provides specific information about the resources, claims, and impacts of their transactions. Thus, the MSMEs' financial statements can present financial information about the performance achievement and financial position that is useful for the decisionmakers. The financial statements of MSMEs of rice farmers groups will generate relevant, transparent, and accountable information.

MSMEs of rice farmers groups in Indonesia can use the results of this study in preparing their financial statements. The building blocks formed from specific elements of financial statements according to the characteristics of MSMEs of rice farmer groups, as described in Table 2, are the novelty of this study. The results of this study provide space for further research to design financial statements for MSMEs of rice farmers groups. Future research can also be carried out to describe the elements of a financial statement from other types of MSMEs business.

\section{Acknowledgments}

We would like to deeply thank Directorate of Research and Community Service, Directorate General of Strengthening Research and Development, Ministry of Research, Technology and Higher Education of the Republic of Indonesia who has provided funding for our research. Sincere thanks are also rendered to the Center of Research and Community Service of Manado State Polytechnic that has facilitated this research.

\section{References}

1. Ankarath, N., Mehta, K. J., Ghosh, T., and Alkafaji, Y. A. (2015). Understanding IFRS: International Financial Reporting Standards. Jakarta: Index.

2. Azim, Md. and Ara, J. (2015). Accountability of accounting stakeholders. Global Journal of Management and Business Research, 15 (2), 4-10.

3. Bank of Indonesia and the Institution of Indonesian Banking Development. (2015). MSMEs business profile. LPPI's Cooperation with Bank Indonesia.

4. Didin, F., Jusni, and Mochamad, M. (2018). How to measure financial performance. International Journal of Civil Engineering and Technology, 9 (6), 553-557.

5. Financial Accounting Standards Board. 2008. Statement of financial accounting concepts no. 6 elements of financial statements. https://www.fasb.org/jsp/FASB/Document_C/

6. Hasanaj, P. and Kuqi, B. (2019). Analysis of financial statements: the importance of financial indicators in entity. Humanities and Social Science Research, 2 (2), 17-27.

7. Institute of Indonesia Chartered Accountants. (2018a). Financial Accounting Standards for Micro, Small, and Medium Entities. Jakarta: IAl.

8. Institute of Indonesia Chartered Accountants. (2018b). Financial Accounting Standards Part A. Jakarta: IAI.

9. Kieso, D. E., Weygandt, J. J., and Warfield, T. D. (2011). Intermediate accounting: IFRS edition. John Wiley \& Sons, Inc.

10. Lepădatu, G. V. and M. Pîrnău. (2009). Transparency in financial statements (IAS/IFRS). European Research Studies, XII (1), 101-108. 
11. Okoye, P. V. C. and Akenbor, C. O. (2014). Financial reporting framework in Nigeria and the adoption of the international financial reporting standards. International Journal of Business and Economic Development, 2 (1), 52-63.

12. Osadchy, E. A., Akhmetshin, E. M., Amirova, E. F., Bochkareva, T. N., Gazizyanova, Yu, and Yumashev, A. V. (2018). Financial statements of a company as an information base for decision-making in a transforming economy. European Research Studies Journal, XXI (2), 339-350.

13. Rashid, Asfthanorhan, N. A., Johari, R. J., Hamid, N. A., Yazid, A. S., Salleh, F., Abdullah, B., Ismail, A. H., and Rasit, S. A. (2018). Ethics and financial reporting assurance. International Journal of Academic Research in Business and Social Sciences, 8 (11), 1346-1355.

14. Risnaningsih, S. T. and Iriani, N. I. (2018). Improving transparency and accountability of MSME financial statements by using the accrual method. Management and Economics Journal, 2 (2), August.

15. Risnaningsih and Suhendri, H. (2015). Dhi's Screen printing \& Printing and The Joker's Screen printing \& Offset micro-business training and mentoring in Malang. Dedicated Journal, 12, 8-13, May.

16. Risnaningsih and Tanuwidjaja, S. (2015). The application of accounting with the accrual basis method in Batik Malangan SMEs Bandungrejosari District Malang. Journal of Reform, 5 (2), 267-272.

17. Smith, S. S. (2015). Accounting, governance and stakeholder reporting, and economic value creation. Journal of Applied Business and Economics, 17 (2), 76-80.

18. Thalassinos, I. E., and Liapis, K. (2014). Segmental financial reporting and the internationalization of the banking sector. Chapter book in, Risk Management: Strategies for Economic Development and Challenges in the Financial System, (eds), D. Milos Sprcic, Nova Publishers, 221-255.

19. Warsono, S., Darmawan, A., and Ridha, M. A. (2010). MSME accounting turned out to be easy to understand and practice. Yogyakarta: Asgard Chapter. 